\title{
Feeding habits of the frog Pleurodema diplolistris (Anura, Leptodactylidae) in Quaternary sand dunes of the Middle Rio São Francisco, Bahia, Brazil
}

José Wellington Alves dos Santos ${ }^{1}$, Roberta Pacheco Damasceno ${ }^{1}$ and Pedro Luís Bernardo da Rocha ${ }^{2}$

${ }^{1}$ Departamento de Zoologia, Instituto de Biociências, Universidade de São Paulo, 05508-900, São Paulo, SP, Brazil.

${ }^{2}$ Departamento de Zoologia, Instituto de Biologia, Universidade Federal da Bahia, 40170-210, Salvador, BA, Brazil.

E-mail: peurocha@ufba.br.

\begin{abstract}
In this work, we investigate the feeding habits of Pleurodema diplolistris, the most abundant anuran species of the São Francisco sand dunes, during a period of slightly over one year. The fieldwork was undertaken during four excursions to a sand dune in the semiarid Caatinga, Brazil, and the analyses were based on stomach contents. Pleurodema diplolistris were not active during the dry season. The important food categories in diet were Isoptera (winged forms), Coleoptera, and Formicidae. Small and large animals had different food consumption patterns: small frogs showed positive electivity for termites and large frogs, for ants. This pattern was strongly influenced by large male food electivity. High levels of termites consumption occurred during the days of greater capture success. The pattern of high consumption of termites detected here is different from that described in another study on lizards from the same locality and sampled in the same periods. We discuss alternative hypotheses that could explain the observed patterns.
\end{abstract}

Keywords: Anura, Leptodactylidae, Pleurodema diplolistris, diet, Caatinga, Quaternary sand dunes, Brazil.

\section{Introduction}

The diet of a predator population is the result of a complex interaction between its features and those of its prey. Although a frog can coexist in its habitat with a great variety of potential food items, its diet composition will be

Received 16 May 2003.

Accepted 20 November 2003.

Distributed 19 December 2003. influenced by prey size, mobility, palatability, and nutritive value (prey organism characters), by prey availability and abundance (prey population characters, which are locally affected by physical and ecological conditions), by the frog's own genetic based characters (physiological, morphological, behavioral) which were subjected to evolutionary processes, and by its previous experiences (Stebbins and Cohen 1995, Pough et al. 1998).

The adaptive radiation of the genus Pleurodema, a small $(<60 \mathrm{~mm})$ toad-like anuran, may have occurred during Tertiary 
climatic oscillations, involving the modification of its reproductive biology and behavior in response to the spread of xeric environments (Duellman and Veloso 1977). The Caatinga is the most xeric of Brazilian biomes and the only species in the genus Pleurodema present in this Brazilian biome and in adjacent open areas is P. diplolistris (Cardoso and Arzabe 1993). Aspects of its morphology (prominent conical tarsal tubercle), behavior (pattern of vocalization, explosive breeding, omnivory and cannibalism in tadpoles, burrowing habit in juvenile and adults), and life cycle (fast larval development) suggest it attains the highest degree of aptation (sensu Gould and Vrba 1982: an organismal character, regardless of whether its phylogenetic origin featured natural selection, that interacts operationally with some factor of its environment so that the individual survives and reproduces) to xeric environmental conditions among the species in the genus and among the species already evaluated in Caatinga anuran communities (Carvalho and Bailey 1948, Peixoto 1982, Cascon 1987, Hödl 1992, Cardoso and Arzabe 1993). However, there are no data available on the diet of adults. Studies on the ecology of Caatinga vertebrates are scant.

In this work, we investigate the feeding habits of Pleurodema diplolistris, the most abundant anuran species in the Quaternary sand dunes of the Middle Rio São Francisco, during a period of slightly over one year, when the dunes were subjected to different amounts of rainfall. We also discuss the possible factors influencing the observed pattern.

\section{Material and Methods}

The Quaternary sand dunes of the Middle Rio São Francisco are located in a strip of arid and semiarid climates extending southwest from Raso da Catarina (Figure 1), where mean annual temperatures are the highest in the state, exceeding $26.2^{\circ} \mathrm{C}$ (Bahia-Seplantec 1978). Records from the closest meteorological station to Ibiraba, in Barra, indicate an annual mean rainfall of $692 \mathrm{~mm}$ (ranging from 400 to 800 $\mathrm{mm}$ ), a dry season of seven to eight months, and a rainy season from October to March (Nimer 1979). Fieldwork was performed in sand dunes of Ibiraba village, Barra municipality, in Bahia state $\left(10^{\circ} 48^{\prime} \mathrm{S}, 42^{\circ} 50^{\prime} \mathrm{W}\right)$.

The sampling areas were located from 200 to $500 \mathrm{~m}$ away from the base of the dunes. Pools were totally absent from the sampling areas given the very low water-holding capacity of the sandy soil and the high level of the valleys compared to the level of the flood plain of the São Francisco river (about $20 \mathrm{~m}$ ). Nevertheless, temporary pools were frequent at the base of the dunes, at the flood plain.

Fieldwork was performed during four field trips of 10 days each: February-March 1996 and February-March 1997 (height of the wet season), September 1996 (height of the dry season), and December 1996 (beginning of the wet season). Anurans were sampled using pitfall-trap grids checked twice a day, at dawn and dusk. All the captured animals (IBAMA license 3451/93-13-AC) exceeding 50 with nonempty stomach per excursion were incorporated undissected into the scientific collection of the Museu de Zoologia da Universidade Federal da Bahia in order to provide a good series of this not previously sampled area. Frogs were euthanized with chloroform, tagged, fixed in $10 \%$ formalin for three days, and then stored in $70 \%$ alcohol. In the laboratory, the random subsample of undamaged animals was dissected, their stomach contents were removed, and their sex was determined. Diet was analyzed by recording, per food category, frequency and wet mass (to $0.01 \mathrm{~g}$ ) after removing the excess water with blotting paper. We measured mass instead of volume of the prey categories because there is a strong correlation between them (Magnusson and Silva 1993) and much criticism about the biases associated with the way volume has traditionally been estimated (Lima et al. 2000). The number of stomachs containing each prey category was divided by the total number of non-empty stomachs and recorded as 


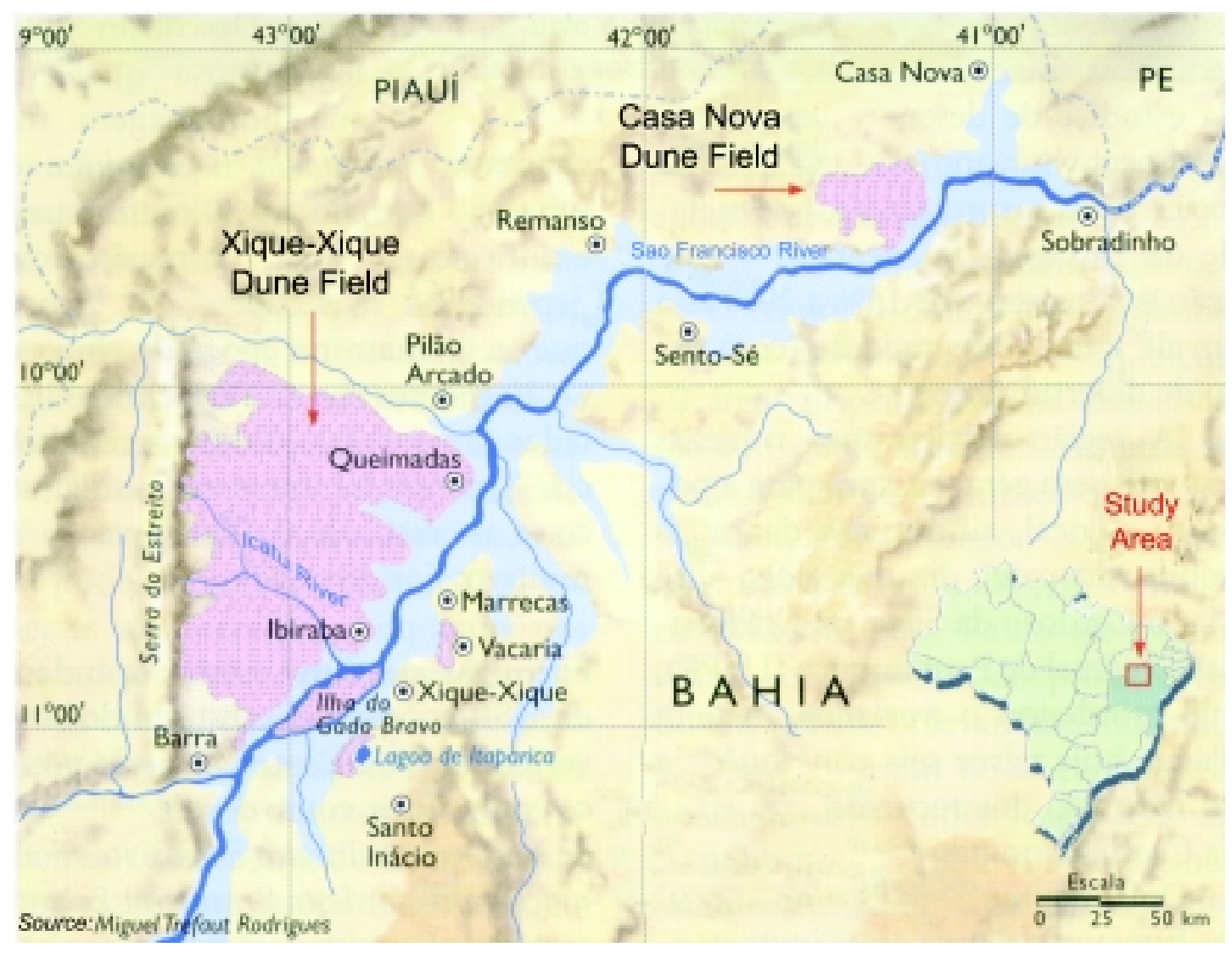

Figure 1 - Location of the São Francisco sand dunes in the State of Bahia, Brazil. Field data were collected at the locality of Ibiraba, near the Icatu River.

occurrence percentage.

In order to analyze ontogenetic changes in diet, we measured the following variables on each undamaged frog with a digital caliper (to the nearest $0.01 \mathrm{~mm}$ ): length from the tip of the snout to the posterior end of urostyle (SUL), jaw length (JL), and mouth width (MW). Jaw apparatus measurements are usually correlated with prey size (Lima et. al. 2000). A strong linear relationship existed between SUL and JL $\left(\mathrm{JL}=1.37+0.26 \mathrm{SUL}, \mathrm{r}^{2}=0.866, \mathrm{P}<0.0001\right.$; runs test: $\mathrm{P}=0.897$ ) and between SUL and MW $\left(\mathrm{MW}=1.24+0.34\right.$ SUL, $\mathrm{r}^{2}=0.901, \mathrm{P}<$ 0.0001 ; runs test: $\mathrm{P}=0.092$ ) (GraphPad Prism, version 3.02, 2000); therefore, results are presented only for tests made with size classes based on SUL (small: 19.33 - $31.77 \mathrm{~mm}$; large: $31.78-44.21 \mathrm{~mm})$.

Diet differences between small and large animals may be influenced not only by their size-based food electivities (sensu Lawlor 1980) but also by their sex, as well as by food availability. Frogs of each size category were further divided by sex (small males $\times$ small females; large males $\times$ large females). Comparisons between these categories were performed using contingency tables (applicable only to enumeration data) using the important prey categories and they are presented as mosaic displays (Zar 1999). Prey categories were 
considered important if they showed high contribution in frequency, mass, and high occurrence percentage in at least two excursions. The male-to-female and large-to-small ratios of each sampled day were evaluated graphically in order to assess evidences of bias in the analyses based on interactions between daily food availability and the activity of different classes of size and sex.

Standardized niche breadth $(B s t)$ based on mass and frequency of prey categories was calculated for each excursion, following Pianka (1986). Low values of niche breadth indicate a major contribution of few prey categories in diet and high values indicate the equitable contributions of many prey categories.

\section{Results}

We sampled 281 Pleurodema diplolistris, which were surface active only at night and only in the rainy season (February-March 1996: 21 individuals; December 1996: 13; and FebruaryMarch 1997: 247). The total number of frogs captured by day was usually small $(0-15)$ except in six peak days: one in February-March 1996 (17) and five in February-March 1997 (18 - 81) (Figure 2A). There were heavy rainfalls in the period of 24 hours before the sample days 5, 16, and 19 (Figure 2A). Small samples precluded statistical analyses with data collected in December 1996. The percentage of small and large animals sampled varied among different field trips. Small animals represented $78.5 \%$ of the total sample in February-March 1996, 15.4\% in December 1996, and only 6.9\% in FebruaryMarch 1997, allowing statistical analyses using small animals' classes only for the first excursion. All the large frogs sampled in the first excursion were collected in one day, as were all the small frogs sampled in the last study period (Figure 2B). Moreover, so few large males were found in February-March 1996 that statistical analyses based on this class were precluded. On most days, the number of sampled females was higher than the number of males, and this difference greatly increased (two to five times) on peak days (Figure 2C).

The diet analysis of all samples (92 stomachs, Table 1) reveled a high contribution (in mass) of Chilopoda (34.3\%), Isoptera (25.3\%, always winged individuals), and Coleoptera $(21.1 \%)$. Chilopoda were consumed only in February-March 1997 (54.1\%) and their mass derived from consumption of a few large items by only five frogs (only $10.6 \%$ of occurrence percentage). The analysis per excursion showed that Isoptera was predominant in February-March 1996 (70.7\% in mass), and that both frequency and occurrence percentage were high in February-March 1996 and February-March 1997. Consumption of Coleoptera showed little temporal change and was widespread in the population (high occurrence percentage). Although Formicidae contributed little to total mass, frequency was high in all periods, and these animals were consumed, at least, by half the frogs every excursion, as were the beetles. Plant tissues, although commonly found in the stomachs, were not considered as a food category because their ingestion either is likely incidental or has no trophic role (Anderson et al. 1999). The number of empty stomachs was low: only one in February-March 1996 and December 1996 (representing 4.3 and $8.3 \%$ of the analyzed stomachs, respectively) and seven in FebruaryMarch 1997 (12.3\%).

Contingency table analyses used the three important prey categories: Isoptera, Coleoptera, and Formicidae (Table 1). Diet comparisons between classes (size and sex) based on the three measurements (SUL, JL, and MW) showed similar results, supporting our previous decision to present only analyses based on SUL.

We detected differences in diet between small and large frogs (Figure 3A). Large frogs ate fewer Isoptera (responsible for $39.1 \%$ of the total calculated chi-square) and more Formicidae than expected (24.2\%), and small ones ate more Isoptera (17.9\%). Analysis per 
(A)

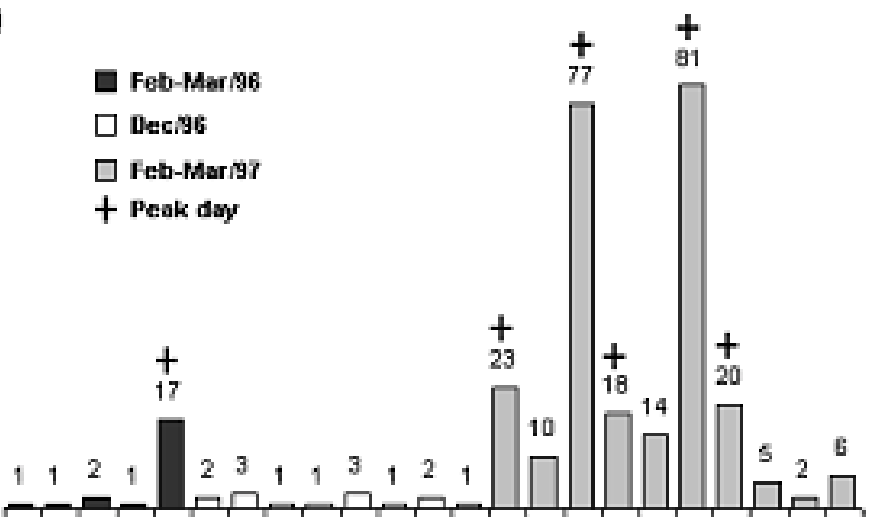

$\begin{array}{lllllllllllllllllllllll} & 2 & 3 & 4 & 5 & 6 & 7 & 8 & 9 & 10 & 11 & 12 & 13 & 14 & 15 & 16 & 17 & 18 & 19 & 20 & 21 & 22 & 23\end{array}$

(日)

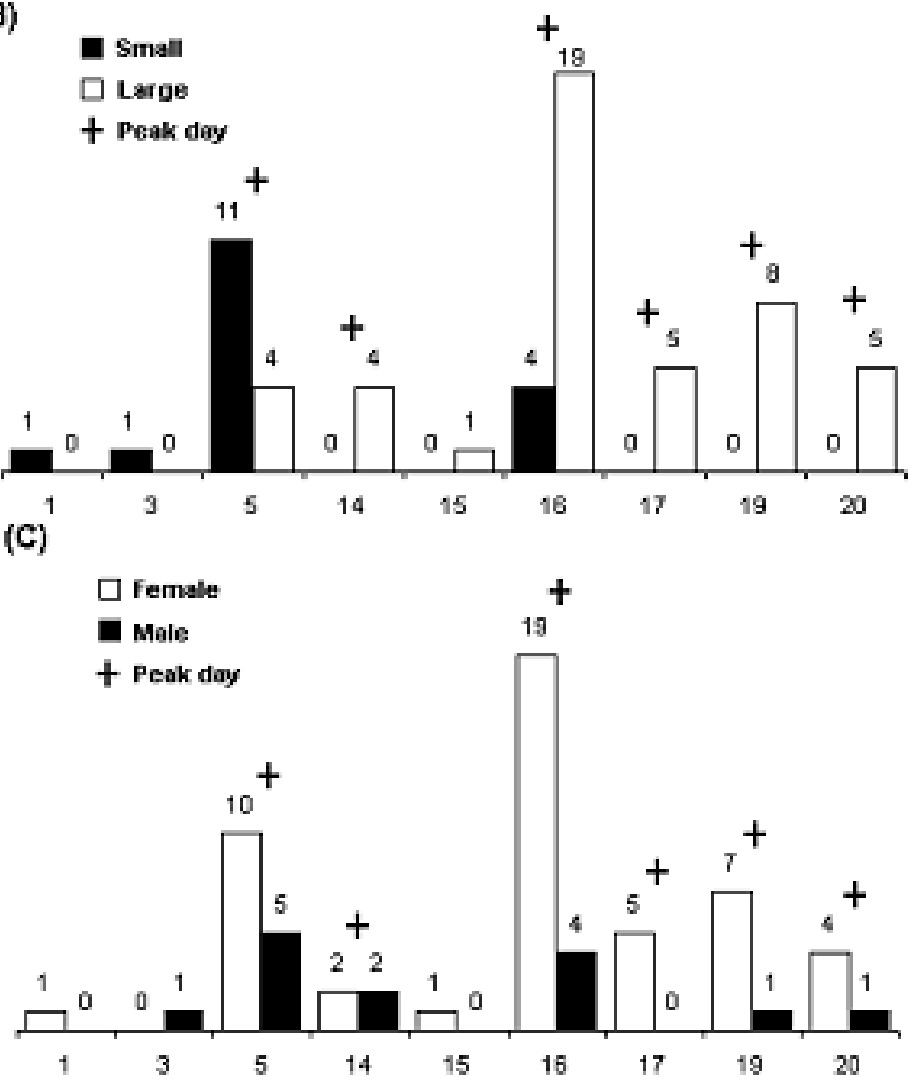

Figure 2 - Frequency of captured and sampled Pleurodema diplolistris per day in the sand dunes of Ibiraba (Bahia, Brazil). (A) Total number of captured frogs per day during February-March 1996, December 1996, and February-March 1997; (B) total number of sampled small and large frogs per day in February-March 1996 and February-March 1997; (C) total number of sampled male and female frogs per day in February-March 1996 and February-March 1997. (*) Capture peak days ( $>15$ frogs). Values on the X-axis represent sample days. 
Table 1 - Stomach contents of 79 specimens of Pleurodema diplolistris collected during three excursions to the sand dunes field of Ibiraba (Bahia, Brazil). N, number of analyzed stomachs (including empty ones); \%f, frequency percentage; $\% \mathrm{~m}$, mass percentage; \%o, occurrence percentage; e.s., empty stomachs (absolute number; percentage). * All Isoptera found in the stomachs were winged individuals.

\begin{tabular}{|c|c|c|c|c|c|c|c|c|c|c|c|c|}
\hline \multirow[t]{2}{*}{ CATEGORY } & \multicolumn{3}{|c|}{$\begin{array}{c}\text { TOTAL } \\
(\mathrm{N}=92) \\
(\text { e.s. }=9 ; 11,39 \%)\end{array}$} & \multicolumn{3}{|c|}{$\begin{array}{c}\text { FEBRUARY-MARCH } 1996 \\
\qquad \begin{array}{c}(\mathrm{N}=23) \\
(\text { e.s. }=1 ; 4,35 \%)\end{array}\end{array}$} & \multicolumn{3}{|c|}{$\begin{array}{l}\text { DECEMBER } 1996 \\
\quad(N=12) \\
(\text { e.s. }=1 ; 8,33 \%)\end{array}$} & \multicolumn{3}{|c|}{$\begin{array}{c}\text { FEBRUARY-MARCH } 1997 \\
\qquad \begin{array}{c}(\mathrm{N}=57) \\
(\text { e.s. }=7 ; 12,28 \%)\end{array}\end{array}$} \\
\hline & $\% f$ & $\% m$ & $\% 0$ & $\% f$ & $\% m$ & $\% 0$ & $\% f$ & $\% m$ & $\% 0$ & $\% f$ & $\% m$ & $\% 0$ \\
\hline Ensifera & 2.16 & 1.77 & 17.72 & 0.70 & 0.38 & 9.52 & 4.88 & 2.65 & 45.45 & 2.46 & 2.06 & 14.89 \\
\hline Blattaria & 0.14 & 2.73 & 1.27 & 0.00 & 0.00 & 0.00 & 0.00 & 0.00 & 0.00 & 0.35 & 4.31 & 2.13 \\
\hline Isoptera* & 27.34 & 25.33 & 46.84 & 45.99 & 70.75 & 66.67 & 3.25 & 15.63 & 36.36 & 18.95 & 11.54 & 40.43 \\
\hline Coleoptera & 17.70 & 21.08 & 62.03 & 17.77 & 19.43 & 85.71 & 27.64 & 28.91 & 63.64 & 13.33 & 19.89 & 51.06 \\
\hline Diptera & 0.43 & 0.13 & 3.80 & 0.70 & 0.38 & 9.52 & 0.00 & 0.00 & 0.00 & 0.35 & 0.07 & 2.13 \\
\hline Formicidae & 36.55 & 7.07 & 68.35 & 25.78 & 4.91 & 85.71 & 30.89 & 16.22 & 63.64 & 49.82 & 5.77 & 61.70 \\
\hline Insect larvae & 1.01 & 2.94 & 8.86 & 0.35 & 0.19 & 4.76 & 1.63 & 19.17 & 18.18 & 1.40 & 0.27 & 8.51 \\
\hline Arthropod eggs and pupae & 1.73 & 0.08 & 2.53 & 0.00 & 0.00 & 0.00 & 5.69 & 0.29 & 9.09 & 1.75 & 0.07 & 2.13 \\
\hline Chilopoda & 0.72 & 34.29 & 6.33 & 0.00 & 0.00 & 0.00 & 0.00 & 0.00 & 0.00 & 1.75 & 54.05 & 10.64 \\
\hline Araneae & 5.04 & 3.16 & 29.11 & 5.92 & 2.64 & 47.62 & 4.07 & 12.68 & 36.36 & 4.56 & 1.19 & 19.15 \\
\hline Acari & 0.58 & 0.17 & 5.06 & 0.19 & 0.19 & 4.76 & 1.63 & 0.59 & 18.18 & 0.35 & 0.07 & 2.13 \\
\hline Gastropoda & 0.14 & 0.04 & 1.27 & 0.19 & 0.19 & 4.76 & 0.00 & 0.00 & 0.00 & 0.00 & 0.00 & 0.00 \\
\hline Flower / Bud flower & 2.16 & 0.13 & 3.80 & 0.19 & 0.19 & 4.76 & 11.38 & 0.59 & 18.18 & 0.00 & 0.00 & 0.00 \\
\hline Other plant tissues & 4.32 & 1.09 & 27.85 & 0.75 & 0.75 & 19.05 & 8.94 & 3.24 & 63.64 & 4.91 & 0.73 & 23.4 \\
\hline TOTAL (absolute values) & 695 & $4.75 \mathrm{~g}$ & - & 287 & $1.06 \mathrm{~g}$ & - & 123 & $0.68 \mathrm{~g}$ & - & 285 & $3.02 \mathrm{~g}$ & - \\
\hline
\end{tabular}

sex, only possible for females, detected that large individuals ate fewer Isoptera $(33.7 \%$ of the total calculated chi-square) than expected (Figure 3B).

Small frogs of different sexes did not differentially used prey categories (Figure 3C). Large males and large females, on the other hand, showed significant differences in prey consumption. The most important differences reside in lower consumption of Isoptera (39.3\% of the total calculated chi-square) and higher consumption of Formicidae (24.9\%) by males, and higher consumption of Isoptera by females (Figure 3D).

Standardized niche breadth reached the highest value in December 1996 (0.529 and 0.496 , based on mass and frequency respectively). At the height of rainy season, the values were lower (0.168 and 0.290 in February-
March 1996 and 0.238 and 0.271 in FebruaryMarch 1997) due to the high consumption of Isoptera and Chilopoda, respectively.

\section{Discussion}

\section{Activity Pattern}

Pleurodema diplolistris from the dunes were surface active only at night and in the rainy season as the other syntopic species of anurans (Rocha 1998). A drastic reduction in activity of the most abundant medium-sized epigeal diurnal lizards during the dry season is also reported for the same area (Rocha 1998). Moreover, during field excursions, we observed that common anuran species from the dunes held in captivity (Pleurodema diplolistris, Bufo granulosus, and Physalaemus albifrons) stayed buried into the 
(A)

$$
\begin{gathered}
\text { Large } M+F \text { (above) } \times \text { Small } M+F \text { (below) } \\
\text { FEB-MAR/1996 } \\
N_{\text {Large }}=5 ; N_{\text {Small }}=12 ; \chi_{0.05,2}^{2}=49.316 ; P<<0.001
\end{gathered}
$$

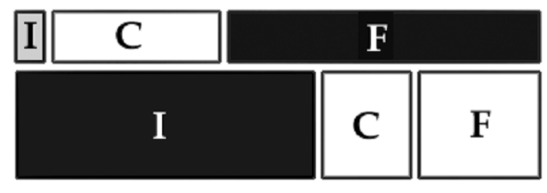

(C)

Small $\mathrm{M} \times$ Small $\mathrm{F}$ FEB-MAR/1996

$N_{M}=5 ; N_{F}=7 ; \chi_{0.05,2}^{2}=1.952 ; 0.25<P<0.50$
(B)

Large $\mathrm{F} \times \mathrm{S}$ Small $\mathrm{F}$ FEB-MAR/1996

$\mathrm{N}_{\text {Large }}=4 ; \mathrm{N}_{\text {Small }}=7 ; \chi_{0.05,2}^{2}=17.466 ; \mathrm{P}<0.001$

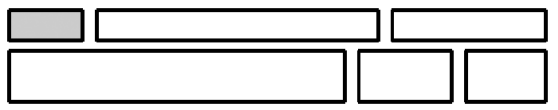

(D)

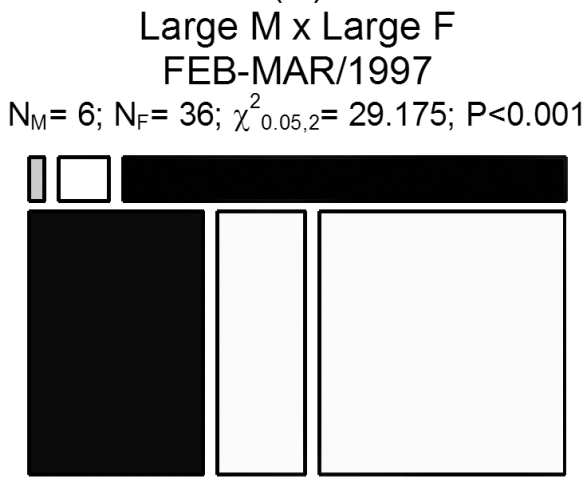

Figure 3 - Mosaic display for the contingency tables comparing frequency of the three important prey categories (I, Isoptera; C, Coleoptera; F, Formicidae) between classes (size and sex) based on stomach contents of Pleurodema diplolistris from the sand dunes field of Ibiraba (Bahia, Brazil). M, males; F, females; N, total number of frogs per analysis; $\mathrm{c}^{2}{ }_{\mathrm{a}, \mathrm{DF}}$, calculated chi-square statistics; a, significance level; DF, degrees of freedom; P, probability. Gray bars indicate observed frequency lower than expected and black bars indicate observed frequency higher than expected; bars thickness are proportional to $\mathrm{N}$ and bars lengths are proportional to observed frequencies.

sand during the day, emerging at night. This pattern is similar to that reported by Cascon (1987) for another population of $P$. diplolistris from the Brazilian Caatinga (municipality of Cabaceiras, Paraíba State) and by Gallardo (1965) for Pleurodema nebulosa in arid zone of northeastern Argentina. Carvalho and Bailey (1948) observed the fossorial habits of $P$. diplolistris in other Caatinga localities in Bahia, Brazil, and showed that they are similar to those of spadefoot toads (Scaphiopus) from North
American deserts. These authors reported that during the day individual $P$. diplolistris remained inside burrows up to $65 \mathrm{~cm}$ below the surface.

\section{Sexual Maturity and Sex Ratio}

Most of the females captured in the dunes during this study were sexually mature (unpublished data) indicating that mainly adult frogs inhabit this area. We have observed explosive reproduction of $P$. diplolistris in pools 
located near the base of the dunes during the most rainy days in February-March 1996 and February-March 1997. Because the distance between sampling areas and these pools was at least $200 \mathrm{~m}$, either the animals at the dunes have high dispersal ability or they may not be able to reproduce.

Differences in male/female ratios in the samples could reflect a sex ratio far different from 1:1 (suggesting higher predation on males), differences in activity between the sexes (females being more active) or both.

\section{Diet}

The important food categories in the diet of Pleurodema diplolistris in the dunes are similar to those found in many studies that reported that termites, ants, and beetles are the principal food categories of many species of frogs in many regions (e.g., Amazonia - Vitt and Caldwell 1994; Cerrado - Moreira 1993; Amazonian savanna Strüssmann et al. 1984). Our results also agree with Polis' argument that vertebrate arthropod feeders, as a group, tend to be resource generalists that include arthropods from various trophic levels in their diets (Polis 1991).

The low percentage of empty stomachs and the marked presence of a soft prey as termites in diet indicate that little change in the results should occur because of digestion. Moreover, there was usually water inside the traps, what could lower the temperature of captured frogs.

The contingency table tests demonstrated that small and large animals had different food consumption patterns: small frogs showed positive electivity for termites and large frogs, for ants. Moreover, this pattern is strongly influenced by large male food electivity, because (1) the differences in food preferences between large and small frogs is similar to that between large males and large females, (2) small frogs of different sexes eat prey categories similarly, and (3) there are only small differences in food electivities between large and small females (Figure 3).
The high consumption of termites by $P$. diplolistris occurred in the peak days. One possible explanation of this fact is that the availability of high quality food supply (Isoptera's availability) may determine the increase of activity by the frogs. This explanation is based on the premise that a great increase of high quality food supply favors selective foraging and leads to a narrowing of the trophic niche breadth (as proposed by Estabrook and Dunham 1976). In fact, in February-March 1996 (height of rainy season), when this prey category was widely consumed by the frogs, the standardized niche breadth (Bst) was narrower (0.290) than in the beginning of the wet season (0.496), indicating a major consumption of few prey categories during the height of the rainy season. However, an alternative explanation is that both phenomena (high termite consumption and increase in frogs' activity) might be caused by a third one, namely the occurrence of heavy rainfalls. This causal factor would also be able to explain the observed pattern of diet, increase in activity and narrowing of niche breadth, as frogs are particularly susceptible to the moisture conditions of the environment (Duellman and Trueb 1994) and swarms of winged termites generally follow heavy rainfalls (Pianka 1986, Cloudsley-Thompson 1991).

Termites were highly consumed by frogs but were absent from the diet of a syntopic lizard community (Rocha 1998). The pattern of high consumption of termites by $P$. diplolistris and their absence from the diet of the syntopic lizard community can be explained by two alternative explanations: in the first one, the presence of termites in frogs' diet and its absence from lizards' diet is a pattern of resource partition that originated through competition between community components. Although data were available only for the rainy season, it was shown to be the only period of frog activity and the period of maximal lizard activity, and therefore the only period of potential ecological interaction between them. On the other hand, the 
second explanation proposes that frogs and lizards eat termites differently because the emergence of the winged termite forms follows the heaviest rainfalls when moisture is high and the sand is wet, favoring anuran activity and reducing the thermoregulatory ability, and therefore the activity, of lizards.

The analysis of capture data by pitfall traps shows that only frogs were active in the heavy rainy days in February-March 1996 and February-March 1997 and that frog captures were inversely related to lizard captures (unpublished data). Lima et al. (2000) found a completely different pattern in diets of sympatric lizards and frogs: termites as an important prey most eaten by lizards and generally absent from frogs' diets. This difference could be explained if the termites eaten by these lizards were not winged forms (this information, however, was not presented in the paper). Differently, Caldwell and Vitt (1999) have found that the importance of termites in diet varied among species of frogs and among species of lizards from one locality at a transitional northern Amazonian rain forest.

Although most of ecological literature in the field of herpetology has emphasized adaptive post hoc explanations for resource use patterns (Cruz 2003), alternative non-adaptive explanations, as those presented here for our data, are important in the sense that they can promote the theoretical development of the field. Further work may test the alternative hypotheses.

\section{Acknowledgements}

We thank W. E. Magnusson and W. Hödl for reviewing a previous version of this manuscript. This study was partially funded by Fundação O Boticário de Proteção à Natureza and CADCT/ SEPLANTEC-BA. JWAS was supported by fellowships from Conselho Nacional de Desenvolvimento Científico e Tecnológico (CNPq) and PRPPG-UFBA numbers 521458/95-(1) and 107636/97-(2).

\section{References}

Anderson, A. N., D. A. Haukos and J. T. Anderson. 1999. Diet composition of three anurans from the playa wetlands of northwest Texas. Copeia 1999: 515-520.

Bahia-Seplantec. 1978. Atlas do Estado da Bahia (50 mapas). Salvador, CEPLAB.

Caldwell, J. P. and L. J. Vitt. 1999. Dietary asymmetry in leaf litter frogs and lizards in a transitional northern Amazonian rain forest. Oikos 84: 383-397.

Cardoso, A. J. and C. Arzabe. 1993. Corte e desenvolvimento larvário de Pleurodema diplolistris (Anura: Leptodactylidae). Revista Brasileira de Biologia 53: $555-560$

Carvalho, A. L. and J. R. Bailey. 1948. Sôbre os hábitos e ecologia de Pleurodema diplolistris (Peters) (Amphibia, Anura). Revista Brasileira de Biologia 8: 261-264.

Cascon, P. 1987. Observações sobre diversidade, ecologia e reprodução da anurofauna de uma área de caatinga. Unpublished M.Sc. Dissertation. Universidade Federal da Paraíba, Brazil.

Cloudsley-Thompson, J. L. 1991. Ecophysiology of Desert Arthropods and Reptiles. Berlin. Springer-Verlag. 203 pp.

Cruz. L. C. 2003. A prática científica na Ecologia de Comunidades: um estudo da literatura de ecologia de comunidades de lagartos. Unpublished M.Sc. Dissertation. Universidade Federal da Bahia, Brazil.

Duellman, W. E. and L. Trueb. 1994. Biology of Amphibians. Baltimore. Johns Hopkins. 670 pp.

Duellman, W. E. and A. M. Veloso. 1977. Phylogeny of Pleurodema (Anura: Leptodactylidae): a biogeographic model. Occasional Papers of the Museum of Natural History of the University of Kansas 64: 1-46.

Estabrook, G. F. and A. E. Dunham. 1976. Optimal diet as a function of absolute abundance, relative abundance and relative prey value of available prey. American Naturalist 110: 401-413.

Gallardo, J. M. 1965. Consideraciones zoogeograficas y ecologicas sobre los anfibios de la Provincia de la Pampa Argentina. Revista del Museo Argentino de Ciencias Naturales Bernardino Rivadavia, Ecologia 1: $57-78$.

Gould, S. J. and S. Vrba. 1982. Exaptation - a missing term in the science of form. Paleobiology 3: 23-40.

Hödl, W. 1992. Reproductive behavior in the neotropical foam-nesting frog Pleurodema diplolistris (Leptodactylidae). Amphibia-Reptilia 13: 263-274.

Lawlor, L. R. 1980. Overlap, similarity, and competition coefficients. Ecology 61: 245-251. 
Lima, A. P., W. E. Magnusson and D. G. Williams. 2000. Differences in diet among frogs and lizards coexisting in subtropical forests of Australia. Journal of Herpetology 34: 40-46.

Magnusson, W. E. and E. V. Silva. 1993. Relative effects of size, season and species on the diets of some amazonian savanna lizards. Journal of Herpetology 27: $380-385$

Moreira, G. R. S. 1993. Padrões de reprodução, atividade e alimentação de anuros em duas localidades do Brasil central. Unpublished M.Sc. Dissertation. Universidade de Brasília, Brazil.

Nimer, E. 1979. Climatologia do Brasil. Rio de Janeiro. IBGE. 421 pp.

Peixoto, O. L. 1982. Observações sobre a larva de Pleurodema diplolistris (Peters 1870) (Amphibia, Anura, Leptodactylidae). Revista Brasileira de Biologia 42: 631-633.

Pianka, E. R. 1986. Ecology and Natural History of Desert Lizards. Princeton. Princeton University Press. 208 pp.

Polis, G. A. 1991. Food webs in desert communities: complexity via diversity and omnivory. Pp. 383-437 in G. A. Polis (ed.), The Ecology of Desert Communities. Arizona. University of Arizona Press.

Pough, F. H., J. B. Heiser and W. N. McFarland. 1998. Vertebrate Life. Upper Saddle River. Prentice Hall. 798 pp.

Rocha, P. L. B. 1998. Uso e partição de recursos pelas espécies de lagartos das dunas do rio São Francisco, Bahia (Squamata). Unpublished Ph.D. Thesis. Universidade de São Paulo, Brazil.

Stebbins, R. C. and N. W. Cohen. 1995. A Natural History of Amphibians. Princeton. Princeton University Press. $316 \mathrm{pp}$.

Strüssmann, C., M. B. R. Vale, M. H. Meneghini, and W. E. Magnusson. 1984. Diet and foraging mode of Bufo marinus and Leptodactylus ocellatus. Journal of Herpetology 18: 138-146.

Vitt, L. J. and J. P. Caldwell. 1994. Resource utilization and guild structure of small vertebrates in the Amazon forest leaf litter. Journal of Zoology 234: 463-476.

Zar, J. H. 1999. Biostatistical Analysis. 4th ed. Upper Saddle River. Prentice Hall. 663 pp. 